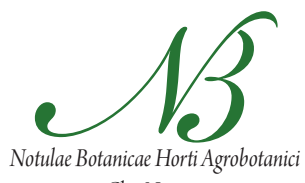

Cluj-Napoca

\title{
High Frequency Plant Regeneration System of Aerides odorata Lour. Through Foliar and Shoot Tip Culture
}

\author{
Huidrom Sunitibala DEVI*, Sanglakpam Irabati DEVI, Thingbaijam Dikash SINGH \\ Institute of Bioresources and Sustainable Development, Medicinal Plants and Horticultural Resources Division, Takyelpat \\ Institutional Area, Imphal-795 001, Manipur, India; sunitibala.ibsd@nic.in (*correspondingauthor)
}

\begin{abstract}
An efficient protocol for rapid clonal propagation from different explants of Aerides odorata Lour.- an endemic orchid of Manipur has been established. Leaf base explants showed significant response in $1 / 2$ strength Murashige and Skoog medium supplemented with thidiazuron (TDZ) and 6-benzylaminopurine (BAP). Callus were initiated only from leaf base explants after 60 days of culture while other parts of leaves failed to response in all the treatments. Medium supplemented with $1.0 \mathrm{mg} / \mathrm{L} \mathrm{TDZ}$ produced protocorm like bodies (PLBs) at the leaf base. Shoot tip explants of $A$. odorata showed different morphogenetic responses in different phytohormone treatments. Calli were initiated only in the medium containing $\alpha$-naphthalene acetic acid (NAA). Highest calli frequency was observed in the medium containing $2 \mathrm{mg} / \mathrm{L}$ (NAA) $(85.71 \pm 0.21)$ which indicates the importance of exogenous auxin in embryonic callus proliferation. Direct shoot regeneration on the other hand was observed in all the treatments. Highest number of shoot was obtained in higher concentration of NAA $(2 \mathrm{mg} / \mathrm{L})$ and BAP $(4 \mathrm{mg} / \mathrm{L})(4.80 \pm 0.18)$, showing combined effect of BAP and NAA, which may be due to the synergistic effect of cytokinin and auxin. Among the different rooting phytohormones, addition of NAA $(0.5 \mathrm{mg} / \mathrm{L}) \mathrm{in} 1 / 2$ MS medium shows highest frequency of root induction. More than $95 \%$ in vitro plants survived during acclimatization under ex vitro conditions. This phytohormones and explants based micropropagation system can open up the route for in vitro clonal multiplication of this commercially important Aerides species.
\end{abstract}

Keywords: 6-benzylaminopurine, callus, naphthalene acetic acid, organogenesis, PLBs, thidiazuron

Abbreviations: PLBs- protocorm like bodies; NAA- $\alpha$-naphthalene acetic acid; TDZ- thidiazuron; $\mathrm{BAP}$ - 6-benzylaminopurine; $\mathrm{HgCl}_{2}$ mercuric chloride; MS- Murashige and Skoog's; IAA- Indole-3-acetic acid; IBA- Indole-3-butyric acid

\section{Introduction}

Aerides as described by de Loureiro (1790) consists of approximately 21 Southeast Asian species ranging from India to Papua New Guinea (Kocyan et al., 2008). Plants are medium to large sized epi- or lithophytes, mostly pinkish coloured with heavily scented flowers. Their fragrance has made them a valuable source for the scent extraction and production of numerous artificial hybrids and cultivars. As a result, they are highly valued in flori-trade as species or hybrids for pot plant or cut flower and holds enormous promise (Kishor et al., 2006). In north-east India, Manipur is rich in orchid biodiversity and occupies the fourth position in orchid diversity (Medhi and Chakrabarti, 2009). Among 251 wild orchid species found in Manipur, Aerides is an endemic and commercially one of the prospective orchids with great medicinal significance. "Meitei maiba- a traditional healer" used ground fruit mainly for healing of wounds while juice of its fleshy leaves is used for the healing of boils in ear and nose. Presence of phenanthropyran derivative and antibacterial effect were also documented by Anuradha and Prakasa (1998) and Ghanaksh and Kaushik (1999) respectively. The grim possibility of extinction un- der intense biotic pressures like forest fires, indiscriminate wild collection and illegal trade by local people of $\mathrm{Ma}$ nipur bring about loss of this native orchid. Traditional knowledge in conservation of orchids in natural habitat by "Meitei" community in sacred groves (Khumbongmayum et al., 2004) can clutch only limited number of orchid genera. However, highly threatened species such as Aerides entail immediate in situ as well as ex situ conservation. Moreover, the propagation of this species through sexual means is a very slow process as its seeds lack endosperm and need fungal stimulant for germination in nature; the fungus is believed to augment the carbohydrate, auxin and vitamin transport in the orchid (Arditti et al., 1982). The loss of diversity in Aerides population however, required to take initiative for the mass propagation and establish in its nature. Thus, tissue culture technique is a potential alternative method for large scale production and conservation of rare, endangered and threatened orchid.

In the present study reliable cloning methodology has been established for this orchid and investigation was undertaken to develop an efficient protocol for in vitro shoot multiplication of Aerides odorata Lour. The results of these experiments provide for the first time a standardized pro- 
170

tocol for plant regeneration through direct and indirect organogenesis in $A$. odorata through leaf and shoot tip explants. In vitro raised plants were used to conserve the genetic stocks of this valuable plant.

\section{Material and methods}

\section{Plant material}

Plants of Aerides odorata Lour. collected from its natural habitat were planted in pots and grown under shade house (50\%) conditions at Institute of Bioresources and Sustainable Development, Imphal, India. During the flowering season, several flowers were hand pollinated on the $2^{\text {nd }}$ day of anthesis and bagged with butter paper for a week. Several pods were harvested after 120 days and brought to the laboratory for in vitro germination.

In vitro establishment of shoot cultures of immature embryos

The harvested pods were surface decontaminated sequentially with detergent solution (Labolene, Qualigens, India) for $10 \mathrm{~min}, 0.1 \%$ streptomycin $(20 \mathrm{~s}), 70 \%(\mathrm{v} / \mathrm{v})$ ethanol (50 s) and $0.1 \%(\mathrm{w} / \mathrm{v})$ mercuric chloride $\left(\mathrm{HgCl}_{2}\right)$ ( $2 \mathrm{~min}$ ), and thoroughly rinsed with sterilized distilled water. Green capsules were dissected longitudinally with sterile surgical blade. The immature seeds were scooped out of the sterilized capsules and small mass $(5 \mathrm{~mm} \times 5 \mathrm{~mm})$ of the aggregated seeds were germinated in $25 \mathrm{~mm} \times 150$ $\mathrm{mm}$ test tube, each containing half strength MS medium (Murashige and Skoog, 1962).

\section{In vitro response of explants types in different} phytohormones

Half strength MS medium supplemented with 3.0\% sucrose and $0.8 \%$ agar (HiMedia, Mumbai, India) was used as a basal medium for in vitro response of $A$. odorata in different explants, unless otherwise noted.

In vitro derived leaves and shoot tips from 38 weeks old axenic cultures harvested from mother plants were used as a source of explants for series of experiments. For investigating the in vitro response of leaf explants to different plant growth regulators, in vitro leaves adjacent to youngest leaves were selected and cut into $5.0-10 \mathrm{~mm}$ segments under aseptic condition (the segments included leaf tip, middle and basal portions). The explants were than culture in $1 / 2 \mathrm{MS}$ medium supplemented with various concentration of Thidiazuron $(0.1-4.0 \mathrm{mg} / \mathrm{L} \mathrm{TDZ})$ and 6-Benzylaminopurine (0.5-8.0 mg/L BAP) (Sigma, USA). For second experimental series, in vitro shoot tip explants of $0.3-0.5 \mathrm{~mm}$ were cultured in $1 / 2$ MS medium supplemented with various concentrations and combinations of $\alpha$-naphthalene acetic acid (0.5-2.0 mg/L NAA), TDZ $(1.0-4.0 \mathrm{mg} / \mathrm{L})$ and BAP $(0.5-4.0 \mathrm{mg} / \mathrm{L})$ (Sigma, USA).

Each of the individual explant was inoculated per 100 $\mathrm{ml}$ conical flask (Borosil, India) containing $50 \mathrm{ml}$ of the medium. 20 vessels were taken per treatment and the ex- periment was repeated three times. The $\mathrm{pH}$ of medium was adjusted to 5.7 and autoclaved at $121^{\circ} \mathrm{C}$ at a pressure of $1.06 \mathrm{~kg} / \mathrm{cm}^{2}$ for $15 \mathrm{~min}$. Cultures were incubated at 25 $\pm 2^{\circ} \mathrm{C}$ under $12 \mathrm{hr}$ photoperiod of 3,500 lux light intensity (Fluorescent tubes $-40 \mathrm{~W}$; Philips India Ltd., Mumbai, India). The observations were made regularly and data were recorded accordingly.

\section{Rooting of regenerated shoots}

For the induction of roots, the regenerated multiple shoots of $A$. odorata were excised and single shoots longer than $2 \mathrm{~cm}$ were transferred to $1 / 2 \mathrm{MS}$ medium supplemented with various rooting hormones viz. NAA, IAA (Indole-3-acetic acid), IBA (Indole-3-butyric acid) (0.5 $\mathrm{mg} / \mathrm{L}$ ). The cultures were maintained in the culture room under the same condition as above experiment. Observation was recorded at regular intervals of 10-15 days upto 120 days and the obtained root number and their length were recorded.

\section{Acclimatization}

In vitro derived plantlets with well developed root system were subjected for ex vitro establishment in soil. Plantlets were washed thoroughly with sterile distilled water to remove any trace of medium and were planted in plastic pot of size $10 \times 12 \mathrm{~cm}$ containing potting mixture of brick chip and charcoal pieces in 1:1 ratio. The acclimatized plants were maintained in a plant growth chamber at $95 \%$ relative humidity with $16 \mathrm{~h}$ photoperiod $(30-45 \mu \mathrm{mol}$ $\left.\mathrm{m}^{-2} \mathrm{~s}^{-1}\right)$. The survival efficiency was determined 4 weeks after initial establishment (Number of plant survived after 4 weeks / Total number of plant subjected for acclimatization).

\section{Statistical analysis}

Statistical significance of each experimental treatment on in vitro response of various explant types to different phytohormones were analysed using one way analysis of variance and Tukey's test in SPSS 16.0 (SPSS Inc., Chicago, IL, USA) using at $p \leq 0.05$ level of significance.

\section{Results and discussion}

\section{In vitro response of leaf segment culture}

The morphogenetic response of leaf explants of Aerides odorata cultured in $1 / 2$ MS medium containing varying concentrations of BAP and TDZ is shown in Tab. 1.

In the present investigation $100 \%$ of the leaf base explants successfully produced yellowish and soft calli proliferated from the basal portion within 8 weeks of culture (Fig. 1a), while other leaf explants like leaf tip and middle portion failed to response in all the treatments. This differential response of the juvenile leaves hints at the possibility of the influence of the genotype or the intrinsic factors of the mother plant upon regeneration potential. The study also determined the probability of control of 
Tab. 1. Effect of different concentration of TDZ and BAP on in vitro leaf explants culture of Aerides odorata Lour.

\begin{tabular}{|c|c|c|}
\hline \multicolumn{2}{|c|}{$\begin{array}{l}\text { Plant growth } \\
\text { regulator } \\
(\mathrm{mg} / \mathrm{L})\end{array}$} & \multirow[t]{2}{*}{ Responding explants $(\%) \pm$ S.E. ${ }^{x}$} \\
\hline TDZ & NAA & \\
\hline 0.1 & & $16.6 \pm 0.22^{\text {aa }}$ \\
\hline 0.5 & & $25.0 \pm 0.12^{\mathrm{aab}}$ \\
\hline 1.0 & & $25.0 \pm 0.14^{\mathrm{aab}}$ \\
\hline 2.0 & & $16.0 \pm 0.11^{\text {aa }}$ \\
\hline \multirow[t]{5}{*}{4.0} & & $16.6 \pm 0.08^{\text {aa }}$ \\
\hline & 0.5 & $16.6 \pm 0.21^{\text {aa }}$ \\
\hline & 1.0 & $25.0 \pm 0.09^{\mathrm{aab}}$ \\
\hline & 2.0 & $41.6 \pm 0.10^{\text {aacc }}$ \\
\hline & 4.0 & $25.0 \pm 0.13^{\mathrm{aab}}$ \\
\hline
\end{tabular}

xS.E.: Standard error; Means followed by same letters are not significantly different at the $p \leq 0.05$ level of significance, according to Turkey's comparison test

meristematic potential by some factors emerging from the leaf base tissues. So far induction of well-defined calli from leaf explants has not been documented from $A$. odorata in vitro. Percentage of responding explants varies from 16.0$41.6 \%$, where, medium containing higher BAP concentration $(4.0 \mathrm{mg} / \mathrm{L})$ showed highest significant response $(p \leq$ 0.05 ) after 60 days of culture (Tab. 1). Whereas, medium containing higher than $2.0 \mathrm{mg} / \mathrm{L}$ TDZ showed reduction in percentage explants responds. However, Chen and Chang (2006) and Chen et al. (1999) also reported direct somatic embryogenesis from leaf explants of orchid species in medium containing TDZ. Although calli were developed in all the leaf base explants, the percentage of responding explants varies according to hormonal concentration (Data not shown). In support to the present finding, Mathews and Rao (1985) reported that isolated leaf base cultures are most amenable region for callus proliferation in orchid. Similarly, the leaf base exhibited a greater proliferative potential than leaf tips in many species such as, Ascocenda and Vanda (Fu, 1978), Coelogyne, Dendrobium, Oncidium and Phalaenopsis (Abdul and Hairani, 1990), Renanthera (Seeni and Latha, 1992), and Acampe (Nayak et al., 1997). In contrary, Churchill et al. (1973) observed that among the different parts of the leaf culture, only leaf tips responded by callus formation in Laeliocattleya cv. Portia 'Mayflower' and in vitro grown Epidendrum cv. O’Brienianum.

Among the different treatments, somatic embryogenesis at the leaf bases subsequently turned into protocorm like bodies (PLBs) within 60 days in $1 / 2 \mathrm{MS}$ medium supplemented with $1.0 \mathrm{mg} / \mathrm{L} \mathrm{TDZ} \mathrm{(Fig.} 1 \mathrm{~b}$ and c). Other cytokinin treatment such as BAP does not show any response in PLBs formation. Similar result showing induc-
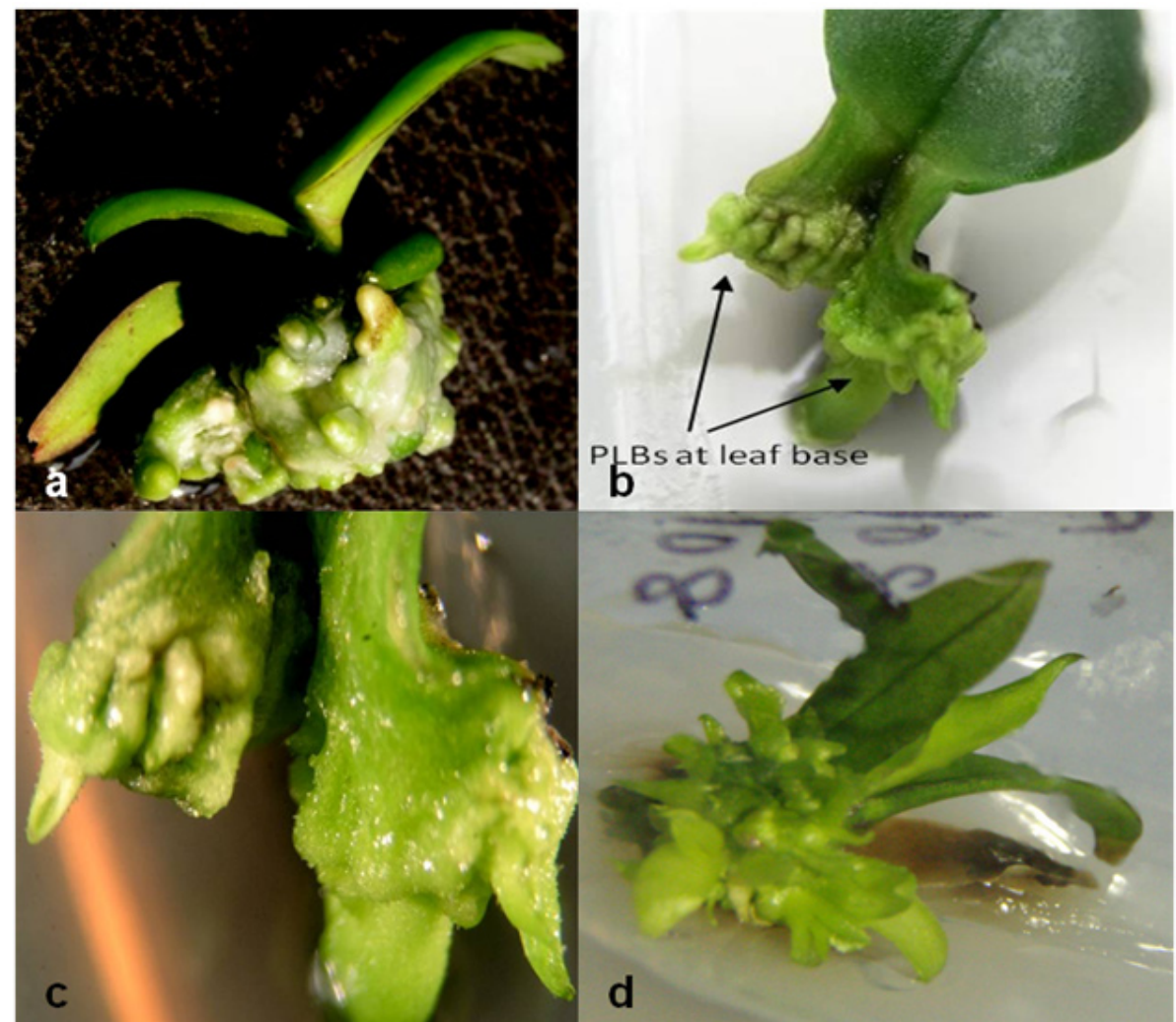

Fig. 1. (a) Induction of callus from base of leaf base segment explants; (b) Induction of protocorm like bodies (PLBs) formation in leaf segment culture of $A$. odoratum on $1 / 2 \mathrm{MS}$ medium + $1.0 \mathrm{mg} / \mathrm{L} \mathrm{TDZ}$; (c) Magnified picture of the area forming PLBs in leaf segment culture seen through a Stereo Zoom microscope; (d) Direct shoot regenerated from base of leaf base segment explant 
172

tion of PLBs from callus was also reported previously by many workers (Kerbauy, 1984; Ishii et al., 1998; Tokuhara and Mii, 2001; Roy and Banerjee, 2003). However, our findings illustrate that TDZ strongly stimulated PLBs (a unique type of somatic embryo in orchids) formation from leaf base explant culture. Chang and Chang (1998), Chen and Chang (2004) and Huan et al. (2004) also demonstrated the response of TDZ in PLBs formation in Cymbidium ensifolium, Oncidium and Cymbidium sp. orchids respectively. Apart from calli and PLBs formation in leaf base explants culture, direct shoot organogenesis were also observed in medium with both the hormones treatment. Formation of direct adventives shoot buds was confined to the leaf bases of the leaves (Fig. 1d) while the chlorophyllous distal parts of the leaves did not show any response in shoot regeneration (Data not shown).

Presently, positive response of foliar explants in successful establishment and multiplication of $A$. odorata in vitro is in support with the finding of Murthy and Pyati (2001) in Aerides maculosum. This indicated the importance of leaf/foliar explants as an effective alternative to shoot meristems for micropropagating orchids which is being increasingly realized. Successful micropropagation using leaf explants depends on many factors like medium nutrient composition, the growth hormones, and most importantly the part of leaf taken. The formation of embryos directly from leaf cells may also provide an opportunity for in vitro cloning, which has not been previously possible because of tissue or callus culture-induced variability.

In vitro response of shoot tip culture

Shoot tip culture of Aerides odorata shows different morphogenetic response in different phytohormones (Tab. 2).
$100 \%$ of the shoot tip explants successfully produced yellowish and soft calli from the base of the shoot tip only in medium supplemented with NAA (Tab. 2). Callus lines were subculture frequently on the original media every $7-8$ weeks interval and were maintained in the same culture condition. After two to three subcultures, callus proliferation was eventually inconsistent with different NAA concentration (Tab. 2). The highest frequency of callus induction was observed on the medium containing $2 \mathrm{mg} / \mathrm{L}$ NAA (85.71\%) (Fig. 2a) while, medium with $1 \mathrm{mg} / \mathrm{L}$ and $4 \mathrm{mg} / \mathrm{L}$ NAA shows callus proliferation of 57 and $28.57 \%$ respectively. However, callus proliferated was absent in medium with $0.5 \mathrm{mg} / \mathrm{L}$ NAA on second subculture but induced only roots. This is consistent with the fact that exogenous auxin is the most important plant growth regulator for induction of embryogenic callus in the majority of angiosperms (Chang and Chang, 1998; Ingacimuthu $e t$ al., 1999Smith and Krikorian, 1990). Orchid callus therefore is considered to be difficult to induce and subculture (Colli and Kerbauy, 1993; Begum et al., 1994; Kerbauy, 1991). Furthermost, our observation in the present study indicated that additional cytokinin were unessential for callus proliferation in $A$. odorata since calli were induced in medium without cytokinin (Tab. 2). In contrary, Chang and Chang (1998), Ishii et al. (1998) and Ingacimuthu et al. (1999) demonstrated the requisite of cytokinin for optimum response that could be related to the maintenance of a proper balance between auxin and cytokinin, which act synergistically to regulate cell division (Johri and Mitra, 2001), a process essential for callus formation. In addition, Roy and Banerjee (2003) have also observed low callus frequency in medium containing NAA alone and suggested that addition of cytokinin was required for improving callus response. Thus callus-embryoid-plant regeneration system developed during the present investigation

Tab. 2. Effect of different phytohormones in in vitro callus induction and shoot multiplication of Aerides odorata Lour.

\begin{tabular}{|c|c|c|c|c|}
\hline \multicolumn{3}{|c|}{$\begin{array}{c}\text { Growth regulators } \\
\mathrm{mg} / \mathrm{L}\end{array}$} & \multirow[t]{2}{*}{ Callus formation $(\%) \pm$ S.E. ${ }^{x}$} & \multirow[t]{2}{*}{ Mean number of auxillary shoots \pm S.E..$^{x}$} \\
\hline NAA & BAP & TDZ & & \\
\hline 0.0 & 0.0 & 0.0 & & $1.25 \pm 0.12^{\mathrm{c}}$ \\
\hline 0.5 & & & $0.00^{\mathrm{a}}$ & $3.29 \pm 0.11^{\mathrm{g}}$ \\
\hline 1.0 & & & $57.00 \pm 0.17^{\mathrm{d}}$ & $2.85 \pm 0.14^{\mathrm{f}}$ \\
\hline 2.0 & & & $85.71 \pm 0.21^{\mathrm{c}}$ & $3.84 \pm 0.25^{\mathrm{g}}$ \\
\hline \multirow[t]{8}{*}{4.0} & & & $26.57 \pm 0.11^{\mathrm{b}}$ & $2.89 \pm 0.15^{\mathrm{f}}$ \\
\hline & 0.5 & & & $2.0 \pm 0.20^{\mathrm{f}}$ \\
\hline & 1.0 & & & $2.2 \pm 0.31^{\mathrm{f}}$ \\
\hline & 2.0 & & & $3.1 \pm 0.30^{\mathrm{g}}$ \\
\hline & 4.0 & & & $4.7 \pm 0.22^{\mathrm{h}}$ \\
\hline & & 1.0 & & $1.6 \pm 0.17^{\mathrm{c}}$ \\
\hline & & 2.0 & & $3.2 \pm 0.23^{\mathrm{g}}$ \\
\hline & & 4.0 & & $3.1 \pm 0.20^{\mathrm{g}}$ \\
\hline 0.5 & 4.0 & & & $3.42 \pm 0.23^{g}$ \\
\hline 1.0 & 2.0 & & & $1.6 \pm 0.19^{\mathrm{c}}$ \\
\hline 2.0 & 4.0 & & & $4.80 \pm 0.18^{\mathrm{h}}$ \\
\hline
\end{tabular}

xS.E.: Standard error; Means followed by same letters are not significantly different at the $p \leq 0.05$ level of significance, according to Turkey's comparison test 
may provide a suitable system for attempts to transform this Aerides species.

Practical protocols for mass propagation of Aerides odorata Lour. were achieved during the present investigation. Statistical analysis on shoot multiplication in $1 / 2 \mathrm{MS}$ medium supplemented with various combination and concentration of NAA, TDZ and BAP have shown significantly $(p \leq 0.5)$ different number of shoots produced among the various treatments (Tab. 2). In this species, shoot bud differentiation occurred directly from the in vitro derived shoot within 10-12 days of culture on medium treated with NAA alone or in combination with BAP. Multiple shoot thus developed were observed without any intervening callus and protocorm like bodies (PLBs) formation. The shoot buds first appeared as small green protuberances which eventually developed into shoots. The differentiation of shoot buds continued until the end of $5^{\text {th }}$ week. The frequency of the shoot regeneration and number of shoots per explants increased with increasing NAA and BAP concentrations (Tab. 2). High frequency shoot

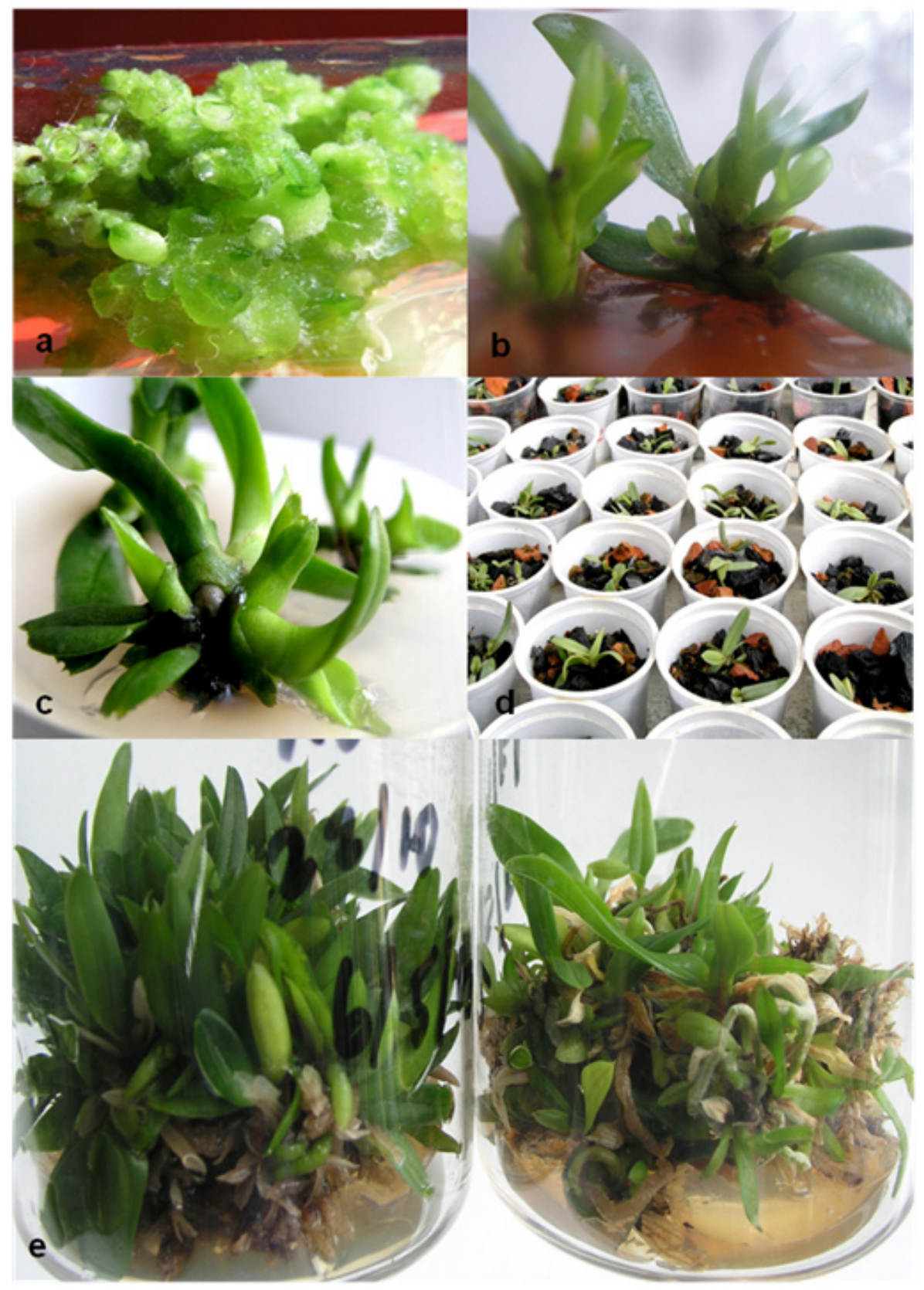

Fig. 2. (a) Callus induction from shoot tip explants; (b) Shoot tip explants forming multiple shoot in $1 / 2 \mathrm{MS}$ medium containing $4 \mathrm{mg} / \mathrm{L} \mathrm{BAP}$; (c) Shoot tip explants forming multiple shoot in $1 / 2 \mathrm{MS}$ medium containing $2 \mathrm{mg} / \mathrm{L}$ NAA $+4 \mathrm{mg} / \mathrm{L}$ BAP; (d) Hardened and transplanted seedlings under shade house; (e) In vitro medium term conservation of $A$. odorata in $1 / 2$ strength MS semisolid medium supplemented with $1 \mathrm{mg} / \mathrm{L} \mathrm{NAA}+2 \mathrm{mg} / \mathrm{L}$ BAP 
174

regeneration (100\%) coupled with maximal number of shoots was recorded at medium with high concentration of BAP $(4 \mathrm{mg} / \mathrm{L})$ treated alone $(4.7 \pm 0.2)$ (Fig. $2 \mathrm{~b})$ or in addition with $2 \mathrm{mg} / \mathrm{L}$ NAA $(4.80 \pm 0.18)$ (Fig. 2c) (Tab. 2). This is in support with the finding of Tripepi (1997) and Huang et al. (2000), showing combined effect of BAP and NAA in shoot multiplication. In contrast Sunitibala and Kishor (2009) have shown reduction in shoot multiplication in high NAA and BAP concentration in Dendrobium transparens. However, the current study has shown that these hormones promoted in vitro shoot multiplication from $A$. odorata shoot tip explant.

Further, addition of TDZ $(1.0-4.0 \mathrm{mg} / \mathrm{L})$ alone though promotes shoot regeneration (1.6 $\pm 0.17-3.2 \pm 0.23)$, which however does not have significant differences with the other treatment such as in NAA (2.85 $\pm 0.14-3.84 \pm 0.84)$. However, least number of shoot multiplication was observed in low concentration $(0.5-1.0 \mathrm{mg} / \mathrm{L})$ of BAP $(2.0 \pm 0.2)$, NAA $(2.85 \pm 0.14)$ and TDZ $(1.6 \pm 0.17)$. Hence, the number of shoot developed is markedly affected by a three-way interaction between NAA, BAP and TDZ concentrations. Thus, the above finding suggests that of the two cytokinins tested, BAP shows significant response for in vitro shoot multiplication in $A$. odorata. Although exogenous cytokinin is regarded as the most crucial factor for shoot induction, in most of the previous studies additional presence of auxin, particularly at a high cytokinin: auxin ratio, has proved more effective than cytokinin alone (Paek and Yeung, 1991; Shimasaki and Uemoto, 1990). Moreover, during the present study, optimum response for shoot multiplication was observed in the higher concentration of auxin and cytokinin (Tab. 2). Therefore, it could be pointed out that exogenous cytokinin is not an absolute prerequisite for shoot induction in orchids and that it simply improves the multiplication rate (Roy and Banerjee, 2002).

\section{Rooting of in vitro derived shoots}

For the rooting of shoots, $1 / 2 \mathrm{MS}$ medium fortified with $0.5 \mathrm{mg} / \mathrm{L}$ of rooting hormone viz. IAA, IBA and NAA were used (Tab. 3). Although, all the tested media positively responded to development of roots, different hormones response different results in number of roots and root length after 3 weeks of culture. Significant rooting response was observed in $1 / 2$ MS medium supplemented with NAA (Tab. 3). Statistically, number of roots of $A$. odorata was found to be highly significant at $5 \%$ level of

Tab. 3. In vitro rooting on half-strength MS medium with different rooting hormones

\begin{tabular}{ccc}
\hline $\begin{array}{c}\text { Plant growth hormones } \\
(0.5 \mathrm{mg} / \mathrm{L})\end{array}$ & $\begin{array}{c}\text { Number of } \\
\text { roots } \pm \text { S.E. }{ }^{\mathrm{x}}\end{array}$ & $\begin{array}{c}\text { Root length } \\
(\mathrm{cm}) \pm \text { S.E. }{ }^{\mathrm{x}}\end{array}$ \\
\hline NAA & $7.5 \pm 0.18^{\mathrm{kn}}$ & $2.43 \pm 0.11^{z z}$ \\
IBA & $4.0 \pm 0.2 \mathrm{l}^{\mathrm{m}}$ & $1.01 \pm 0.44^{z z}$ \\
IAA & $2.6 \pm 0.14^{\mathrm{mx}}$ & $2.0 \pm 0.07^{z z}$ \\
\hline${ }^{\mathrm{x}}$.E.: Standard error & &
\end{tabular}

significance. Among different concentration of NAA highest number of roots was observed in medium with 0.5 $\mathrm{mg} / \mathrm{L}$ NAA with average value of 7.5 per explants. No significant differences were observed in root length ranging from 1.01-2.43 per explants, the highest root length was observed in medium with $0.5 \mathrm{mg} / \mathrm{L}$ NAA $(2.43 \pm 0.11)$. However, in support with the present finding, superiority of NAA in root induction was also reported by Sheelavantmath et al. (2000). Thus, among the different rooting hormones, NAA was found to be most effective for the rooting of shoots of $A$. odorata. This result is in contrary with the previous findings of rooting in Aerides odorata (Pant and Gurung, 2005) and Micropera pallida (Bhadra and Hossain, 2004) showing positive response in medium with IAA. Similarly, Pradhan (2007) and Asghar et al. (2011) observed maximum number of roots on medium fortified with IBA than in NAA in orchid species.

A good growing medium having properties such as maximum water-holding capacity, porosity, drainage and proper environmental condition is essential for proper growth and development of in vitro raised plantlets of $A$. odorata. Hardening of the plants in the greenhouse under high humidity conditions was found to be highly beneficial for successful acclimatization. Well developed in vitro derived shoots along with roots were transfer into soil for ex vitro establishment of $A$. odorata. More than $95 \%$ survival rate were observed in plants hardened at 1:1 ratio brick chips and charcoal pieces (Fig. $2 \mathrm{~d}$ ).

\section{In vitro medium term conservation of Aerides odorata}

A simple and easy technique for medium term in vitro conservation of $A$. odorata has been developed (Fig. 2e). Seedling of $A$. odorata can grow upto 12 months at $1 / 2$ strength MS semisolid medium supplemented with 1 $\mathrm{mg} / \mathrm{L} \mathrm{NAA}+2 \mathrm{mg} / \mathrm{L}$ BAP in culture bottles with polypropylene caps. The cultures can be maintained for more than 24 months by addition of liquid culture medium having same nutrient composition without transferring the seedlings from one culture vessel to another. However, the development of successful storage methods enables the establishment of extensive basal collections, with representative genetic diversity. Using this protocol, it is possible to produce viable uniform and healthy plants with maximum survival rate that can be used for large scale cultivation. Furthermore, the protocol may facilitate conservation of this fragrant, medicinal orchid from extinction in natural population.

\section{Conclusions}

The data presented herein indicate that for rapid multiplication of $A$. odorata using different plant growth hormones could be effectively employed which otherwise exhibits extremely slow growth. This is the first report describing the effect of varying phytohormones in different explants type of $A$. odorata and describes a rapid and simple 
protocol to obtain large numbers of plantlets within short period of time. Interestingly, in conclusion, apart from significant combination effect of NAA and BAP in shoot multiplication, transition of flower in vitro were observed in the medium with $1 \mathrm{mg} / \mathrm{L} \mathrm{NAA}$ and $2 \mathrm{mg} / \mathrm{L} \mathrm{BAP}$. Initiated flower was however incomplete and disappear after the next subculture in the same medium. This may be due to the presence of auxins, which may be involved with the transition to the reproductive phase, which to a certain degree are in accordance with the results of Ferreira et al. (2006) in Dendrobium. Further work to study the various parameters that effect the growth and flowering and phytochemical availability is still underway.

\section{References}

Abdul Karim AG, Hairani H (1990). Leaf culture of some Malaysian orchids, 12-17 p. In: Niar H (Ed.). Proc. International conference and exhibition on orchids and ornamental plants, The Orchid Society of Malaysia, Petaling Jeya, Malaysia.

Anuradha V, Prakash NS (1998). Aeridin: A phenanthropyran from Aerides crispum. Phytochemistry 48(1):185-186.

Arditti J, Clements MA, Fast G, Hadley G, Nishimura G (1982). Orchid seed germination and seedling culture, 243-370 p. In: Arditti J (Ed.). Orchid Biology, Reviews and Perspectives 2, Cornell University Press, New York.

Asghar S, Ahmad T, Hafiz IA, Yaseen M (2011.) In vitro micropropagtion of orchid (Dendrobium nobile) Var. Emma White. Afr J Biotechnol 10(16):3097-3103.

Begum AA, Tamaki M, Tahara M, Kato S (1994). Somatic embryogenesis in Cymbidium through in vitro culture of inner tissue of protocormlike bodies. J Jpn Soc Hortic Sci 63:419427.

Bhadra SK, Hossain MM (2004). Introduction of Embryogenesis and Direct Organogenesis in Micropera pallida Lindl. An epiphytic orchid of Bangladesh. J Orchid Soc India 18(1\&2):5-9.

Chang C, Chang WC (1998). Plant regeneration from callus culture of Cymbidium ensifolium var. misericors. Plant Cell Rep 17:251-255.

Chen JT, Chang C, Chang WC (1999). Direct somatic embryogenesis and subsequent plant regeneration on leaf expants of Oncidium 'Gower Ramsey' in vitro. Plant Cell Rep 19:143149.

Chen JT, Chang WC (2004). Induction of repetitive embryogenesis from seed-derived protocorms of Phalaenopsis amabilis var. Formosa shimadzu. In Vitro Cell Dev Biol Plant 40:290-293.

Chen JT, Chang WC (2006). Direct somatic embryogenesis and plant regeneration from leaf explants of Phalaenopsis amabilis. Biol Plant 50(2):169-173.

Churchill ME, Ball EA, Arditti J (1973). Tissue culture of orchids. I. Methods for leaf tips. New Phytol 72:161-166.
Colli S, Kerbauy GB (1993). Direct root tip conversion of Catasetun into protocorm-like bodies: effect of auxin and cytokinin. Plant Cell Tissue Organ Cult 33:39-44

de Loureiro J (1790). Flora Cochinchinensis: Ulyssipone: typis, et Expensis Academicis.

Ferreira WM, Kerbauy GB, Kraus JE, Pescador R, Suzuki RM (2006). Thiadiazuron influences the endogenous levels of cytokinins and IAA during the flowering of isolated shoots of Dendrobium. J Plant Physiol 163:1126-1134.

Fu FML (1978). Clonal propagation of Aranda, Ascocenda, and Cattleya by leaf tissue culture. Gard Bull Singapore 31:132138.

Ghanaksh A, Kaushik P (1999). Antibacterial effect of Aerides multiflora Roxb. A study in vitro. J Orchid Soc India 13(1/2):65-68.

Huang CL, Hsieh MT, Hsieh WC, Sagare AP, Tsay HS (2000). In vitro propagation of Limonium werightii (Hance) Ktze. (Plumbaginaceae), and ethnomedecinal plant, from shoottip, leaf- and inflorescence-node explants. In Vitro Cell Dev Biol Plant 36:220-224.

Ignacimuthu S, Arockiasamy S, Antonysamy M, Ravichandran P (1999). Plant regeneration through somatic embryogenesis from mature leaf explants of Eryngium foetidum, a condiment. Plant Cell Tiss Organ Cult 56:131-137.

Ishii Y, Takamura T, Goi M, Tanaka M (1998). Callus induction and somatic embryogenesis of Phalaenopsis. Plant Cell Rep 17:446-450.

Johri MM, Mitra D (2001). Action of plant hormones. Curr Sci 80(2): 199-205.

Kerbauy GB (1984). Plant regeneration of Oncidium varicosum (Orchidaceae) by means of root tip culture. Plant Cell Rep 3:27-29.

Khumbongmayum AD, Khan ML, Tripathi RS (2004). Sacred groves of Manipur, ideal centres for biodiversity conservation. Current Science 87(4):430-433.

Kishor R, Sha Valli KPS, Sharma GJ (2006). Hybridization and in vitro culture of an orchid hybrid Ascocenda 'Kangla'. Sci Hortic 108:66-73.

Kocyan A, de Vogel EF, Conti E, Gravendeel B (2008). Molecular phylogeny of Aerides (Orchidaceae) based on one nuclear and two plastid markers: a step forward in understanding the evolution of the Aeridinae. Molecular Phylogenetics and Evolution 48:422-443.

Huan Le Van Tuong, Takamura T, Tanaka M (2004). Callus formation and plant regeneration from callus through somatic embryo structures in Cymbidium orchid. Plant Science 166:1443-1449.

Mathews VH, Rao PS (1985). In vitro culture of Vanda hybrid (Vanda TMA Vanda Miss Joaquim). II. Studies on seedling explant. Proc Indian Natl Sci Acad 51:496-504.

Medhi RP, Chakrabarti S (2009). Traditional Knowledge of NE people on Conservation of Wild Orchids. Indian Journal of Traditional Knowledge 8:11-16. 
176

Murashige T, Skoog F (1962). A revised medium for rapid growth and bioassay with tobacco tissue cultures. Physiol Pl 15:473-497.

Murthy H, Pyati A (2001). Micropropagation of Aerides maculosum Lindl. (Orchidaceae). In Vitro Cell Dev Biol Plant 37:223-226.

Nayak NR, Patnaik S, Rath SP (1997). Direct shoot regeneration from leaf explants of epiphytic orchids Acampe praemorsa (Roxb.) Blatter and McCann. Plant Cell Rep 16(8):583-586.

Paek KY, Yeung EC (1991). The effects of 1-naphthaleneacetic acid and N6-benzyladenine on the growth of Cymbidium forrestii rhizomes in vitro. Plant Cell Tissue Organ Cult 24:65-71.

Pant B, Gurung R (2005). In vitro seed germination and seedling development in Aerides odorata Lour. J Orchid Soc India 19(1\&2):51-55.

Pradhan S (2007). Ex situ conservation of two orchid species viz. Cymbidium elegans Lindl. and Dendrobium densiflorium Lindl. by tissue culture technique. M.Sc. Dissertation, Central Dept Bot TU Kathmandu, Nepal.

Roy J, Banerjee N (2003). Induction of callus and plant regeneration from shoot-tip explants of Dendrobium fimbriatum Lindl. var. Oculatum Hk. Scientia Hortic 97:333-340.
Seeni S, Latha PG (1992). Foliar regeneration of the endangered Red Vanda, Renanthera imschootiana Rolfe (Orchidaceae). Plant Cell Tiss Org Cult 29(3):167-172.

Sheelavantmath SS, Murthy HN, Pyati AN, Kumar HGA, Ravishankar BV (2000). In vitro propagation of the endangered orchid Geodorum densiflorum through rhizome section culture. Plant Cell Tissue Organ Culture 60(2):151-154.

Shimasaki K, Uemoto S (1991). Rhizome induction and plantlet regeneration of Cymbidium goeringii from flower bud cultures in vitro. Plant Cell Tissue Organ Cult 25:49-52.

Smith DL, Krikorian AD (1990). Low external pH replaces 2,4$\mathrm{D}$ in maintaining and multiplying 2,4-D initiated embryogenic cells of carrot. Plant Physiol 72:329-336.

Sunitibala H, Rajkumar K (2009). Micropropagation of Dendrobium transparens $\mathrm{L}$. from axenic pseudobulb segments. Indian J Biotechn 18:448-452.

Tokuhara K, Mii M (1993). Micropropagation of Phalaenopsis and Doritaenopsis by culturing shoot tips of flower stalk buds. Plant Cell Rep 13:7-11.

Tripepi RR (1997). Adventitious shoot regeneration 45-71 p. In: Geneve RL, Preece JE, Merkle SA (Eds.). Biotechnology of Ornamental Plants, CAB International, Wallingford. 